\title{
SEASONAL VARIATIONS OF ZOOPLANKTON FUNCTIONAL GROUPS AND RELATIONSHIP WITH ENVIRONMENTAL FACTORS IN A EUTROPHIC RESERVOIR FROM COLD REGION
}

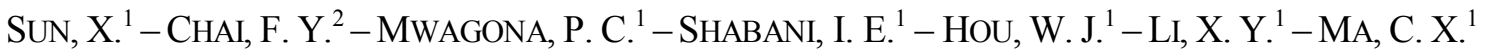 \\ - PAN, H. F. ${ }^{1}-$ LI, S. ${ }^{1}-$ YU, H. X. ${ }^{1 *}$ \\ ${ }^{1}$ Department of Wetland Science, College of Wildlife Resources, Northeast Forestry University, \\ Harbin 150040, China
}

${ }^{2}$ Water Saving Technology Center of Heilongjiang Province, Harbin 150001, China

*Corresponding author

e-mail:china.yhx@163.com

(Received 12 $2^{\text {th }}$ Mar 2019; accepted $3^{\text {rd }}$ May 2019)

\begin{abstract}
In this study, the concept of functional feeding groups was used to classify zooplankton community into functional groups among three seasons (spring, summer and autumn). A total of 30 zooplankton species were sampled in the Tuanjie Reservoir and identified into seven functional groups. Environmental factors and zooplankton functional group biomass were both varied in spatially and seasonally. Water transparency (SD), dissolved oxygen (DO), $\mathrm{pH}, \mathrm{N}: \mathrm{P}$ and dissolved iron $\left(\mathrm{Fe}^{3+}\right)$ were higher in autumn while total phosphorus (TP), chemical oxygen demand $\left(\mathrm{COD}_{\mathrm{Mn}}\right)$ and dissolved copper $\left(\mathrm{Cu}^{2+}\right)$ were higher in spring, and temperature (T) and ammonium nitrogen $\left(\mathrm{NH}_{4}{ }^{+}-\mathrm{N}\right)$ were higher in summer. Zooplankton functional groups biomass was higher in summer, followed by spring and autumn. In spring, zooplankton functional group only dominated by group PF, while in summer and autumn dominated by group PF and RF. Spearman and RDA results showed that SD, conductivity (COND), DO, $\mathrm{NH}_{4}{ }^{+}-\mathrm{N}$, nitrate nitrogen $\left(\mathrm{NO}_{3}{ }^{-}-\mathrm{N}\right)$ and $\mathrm{COD}_{\mathrm{Mn}}$ were the major factors influencing zooplankton functional groups in Tuanjie Reservoir.
\end{abstract}

Keywords: seasonal dynamics, zooplankton functional groups, abundance and biomass, northeast of China

\section{Introduction}

Zooplankton is found in almost all kinds of waterbodies. Compared with other aquatic animals, they are small in size, numerous in numbers and have strong metabolic activities. They feed on phytoplankton, bacteria, fragments and other organisms. Zooplankton also participates in the decomposition and circulation of organic matter in the water ecosystem through excretion and secretion, energy transfer from the primary producers to higher consumers (Wetzel, 2001). Variation of zooplankton can influence the structure of other nutrient levels in water ecosystems (Beaugrand et al., 2000; David et al., 2005; Lobry et al., 2008; Steinberg and Condon, 2009). The zooplankton community structure, their abundance and biomass is influenced by top-down and bottom-up control (Jeppesen et al., 2003), and is one of determinants for water quality (Jeppesen et al., 2011). This is due to the interaction between biological organisms and environmental factors (Ejsmont-Karabin and Karabin, 2013).

Traditional methods of zooplankton classification are usually based on the taxonomy system. However, it is difficult to reflect the aquatic ecological function. Therefore, ecologists have put forward the concept of functional groups, species characteristics of the functional group more closely in touch with environment, through the study of functional groups, can more directly reflect the ecological process of ecological 
environmental impact of aquatic biological communities (Hood et al., 2006). In recent years, the use plankton functional groups have been applied in several studies of biogeochemical models (Anderson, 2005). Zooplankton is divided into three functional groups: mico-, meso- and macrozooplankton (Quéré et al., 2010). By using the concept of functional groups, zooplankton community composition can be used to model the ecosystem process of the aquatic ecosystem and it is also conducive to analyzing the seasonal variation of zooplankton community (Sun et al., 2010).

Tuanjie Reservoir was built in 1981 with the aim of supplying drinking water to the local village people. The main sources water of the reservoir is Muling River, which is the largest tributary of the Ussuri River on the left bank of the border between China and Russia. In this study the concept of functional feeding groups was used to reveal the seasonal variation of zooplankton functional groups in relation to environmental factors in Tuanjie Reservoir. Understanding the variation of zooplankton functional groups biomass in relation to environmental factors is very important to better understand the environmental factors that significantly structure the zooplankton community in the reservoir. This study aims at: (1) identifying and classifying zooplankton species of Tuanjie Reservoir into functional group, and (2) to determine the seasonal and spatial dynamics of the biomass of zooplankton functional groups and their relationship to environmental factors. We hypothesized that seasonal and spatial change in biomass of zooplankton functional groups will be strongly influenced by environmental factors.

\section{Materials and methods}

\section{Study area}

Tuanjie Reservoir $\left(130^{\circ} 8^{\prime}-130^{\circ} 11^{\prime} \mathrm{E}, 44^{\circ} 01^{\prime}-44^{\circ} 04^{\prime} \mathrm{N}\right)$ is located in the southeast of Heilongjiang Province Northeastern China (Fig. 1). The reservoir was built in 1981 in order to control floods, provide water for irrigation, fish farming, power generation and for aesthetic value. Tuanjie Reservoir has a surface area of $445 \mathrm{~km}^{2}$, a capacity of $8.63 \times 10^{7} \mathrm{~m}^{3}$ and it shaped like big " $\mathrm{Y}$ ". The region where located the reservoir is influenced by temperate continental monsoon. The average annual evaporation and precipitation of the reservoir are $950 \mathrm{~mm}$ and $534 \mathrm{~mm}$, respectively. The annual mean temperature is $1{ }^{\circ} \mathrm{C}$, which ranged between $-44.1^{\circ} \mathrm{C}$ to $37.6^{\circ} \mathrm{C}$. In winter, the surface water of the reservoir is covered by ice.

\section{Field sampling and laboratory analysis}

Based on the reservoir shape, 5 sampling sites (Table 1) were selected for sampling on spring (May), summer (July) and autumn (September). Samples were collected from top $(0.5 \mathrm{~m}$ from the surface water $)$, middle and bottom $(0.5 \mathrm{~m}$ from the waterbed) of water column according to the different water depth among sites inside the Tuanjie Reservoir (Fig. 1). At every sampling site, water temperature (T), pH, conductivity (COND), dissolved oxygen (DO) was measured in the field using a portable multi-probe (YSI 6600, YSI Inc.). Water transparency (SD) and depth (D) were measured using Secchi disk and longline method. Triplicate water samples for chemical analyses were collected at each sampling sites and put on acid-washed plastic bottles, placed in ice box and transported to laboratory for analysis. The concentration of total nitrogen (TN), total phosphorus (TP), N:P ratio (N:P), ammonium nitrogen $\left(\mathrm{NH}_{4}{ }^{+}-\mathrm{N}\right)$, nitrate nitrogen $\left(\mathrm{NO}_{3}{ }^{-}-\mathrm{N}\right)$, chemical oxygen demand $\left(\mathrm{COD}_{\mathrm{Mn}}\right)$ and dissolved iron $\left(\mathrm{Fe}^{3+}\right)$ and dissolved 
copper $\left(\mathrm{Cu}^{2+}\right)$ were measured according to the standard methods for China (MEP, 2002).

Table 1. Five sampling sites coordinates in Tuanjie Reservoir

\begin{tabular}{|c|c|c|}
\hline Sampling sites & Latitude & Longitude \\
\hline S1 & $\mathrm{N}^{2} 4^{\circ} 01^{\prime} 48^{\prime \prime}$ & E130॰11'24" \\
\hline S2 & N440'의 & $\mathrm{E} 130^{\circ} 10^{\prime} 48^{\prime \prime}$ \\
\hline S3 & 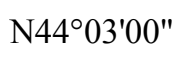 & E13009'36" \\
\hline S4 & N440'ㄴ' & $\mathrm{E} 130^{\circ} 10^{\prime} 36^{\prime \prime}$ \\
\hline S5 & N44운'48" & $\mathrm{E} 130^{\circ} 10^{\prime} 48^{\prime \prime}$ \\
\hline
\end{tabular}
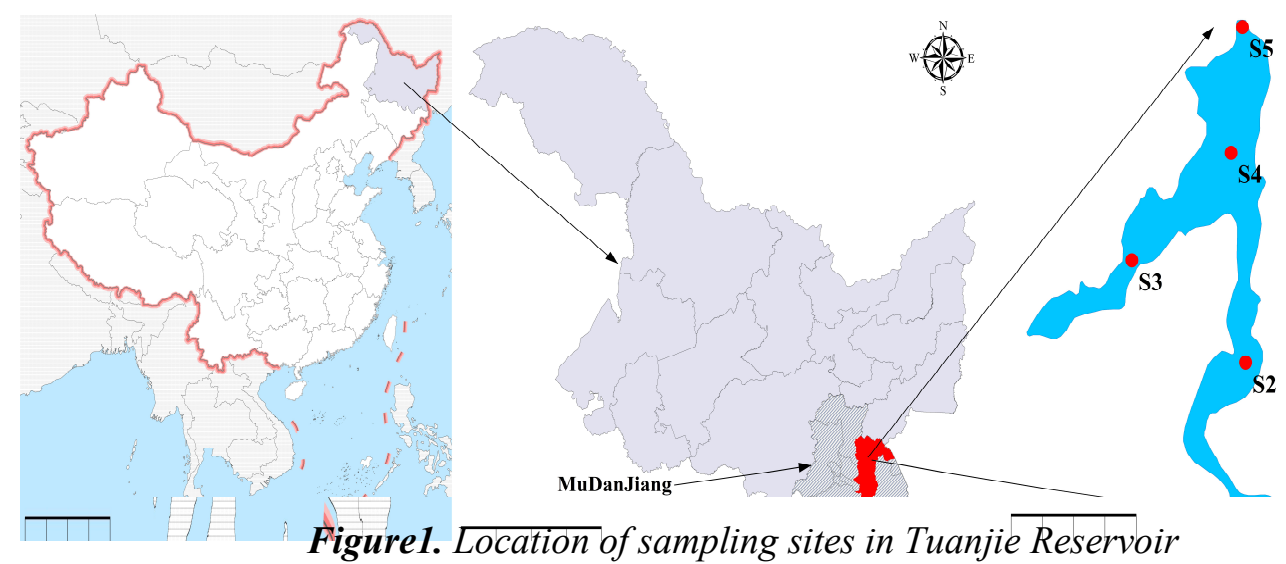

. Location of sampling sites in Tuanjie Reservoir

Zooplankton samples ( $20 \mathrm{~L}$ water filtered through $64 \mathrm{~mm}$ mesh size) were fixed with formaldehyde solution ( $4 \%$ concentration). Protozoa and rotifera samples were obtained by taking $1 \mathrm{~L}$ subsamples to form the $20 \mathrm{~L}$ pooled sample. The samples were preserved with Lugol's iodine and formaldehyde and allowed to sediment in $1 \mathrm{~L}$ jar for at least $48 \mathrm{~h}$. The supernatant water was carefully removed and the residue was then collected and made to a known volume of $30 \mathrm{~mL}$ (Thompson et al., 2013). Identification and counting of the zooplankton specimen were using an inverted microscope at $400 \times$ magnification following the species keys (Chen, 1974; Chiang and Du, 1979; Yeatman, 1959). We calculated zooplankton functional group biomass by using dry weight (mg) obtained from length-weight relationship of the filtered water volume (L) (Zuo et al., 2003).

\section{Zooplankton functional groups classification}

Zooplankton species in Tuanjie Reservoir were classified into seven functional groups mainly according to body size/length and feeding mode (Benedetti et al., 2018; Ma et al., 2019; Mwagona et al., 2018). The seven functional groups are: group PF (protozoa filter feeders), group RF (rotifera filter feeders), group SCF (small copepods and cladoceran filter feeders, body size $<0.7 \mathrm{~mm}$ ), group MCC (middle copepods and cladoceran carnivore, body size $0.7 \sim 1.5 \mathrm{~mm}$ ), group MCF (middle copepods and cladoceran filter feeders, body size $0.7 \sim 1.5 \mathrm{~mm}$ ), group LCC (large copepods and cladoceran carnivore, body size $>1.5 \mathrm{~mm}$ ) and group LCF (large copepod filter feeders, body size $>1.5 \mathrm{~mm}$ ). 


\section{Data analysis}

Statistical analyses were carried out using the SPSS 19.0 software. Variation and correlation of environmental factors and biomass of zooplankton functional groups in different seasons were analyzed by using One-way ANOVA and Tukey's honesty significant difference (HSD) tests, and Spearman analysis, respectively. Relationship between zooplankton functional group biomass and environmental factors was done using CANOCO 4.5 software (Microcomputer Power, New York, USA). Before analysis, the biological and abiotic data were transformed by $\log _{10}(\mathrm{x}+1)$ to satisfy the normal distribution. We found that the detrended corresponding analysis (DCA) of the largest gradient length of the four axes was $1.889(<3)$. Therefore, linear ordination method of the redundancy analysis (RDA) was used to reveal the relationship. Monte Carlo simulations with 499 permutations were used to test the significance of the environmental factors in explaining the biomass of zooplankton functional groups data in the RDA.

\section{Results}

\section{Seasonal variation of environmental factors}

The mean values of environmental factors presented among seasons are shown in Table 2. Most of the factors varied significantly (One-way ANOVA and Tukey HSD test). The mean values of $\mathrm{D}, \mathrm{COND}, \mathrm{TN}$ and $\mathrm{NO}_{3}{ }^{-}-\mathrm{N}$ were not statistically significant difference among the seasons $(P>0.05)$. While the mean values of $\mathrm{DO}, \mathrm{pH}, \mathrm{NH}_{4}{ }^{+}-\mathrm{N}$, $\mathrm{COD}_{\mathrm{Mn}}, \mathrm{Fe}^{3+}, \mathrm{Cu}^{2+}, \mathrm{T}, \mathrm{TP}, \mathrm{N}: \mathrm{P}$ and $\mathrm{SD}$ varied significantly with seasons $(P<0.05)$. The minimum mean values of $\mathrm{DO}, \mathrm{pH}, \mathrm{N}: \mathrm{P}$ and $\mathrm{Fe}^{3+}$ were observed in summer, while their maximum values were observed in autumn except for $\mathrm{COD}_{\mathrm{Mn}}$. On the contrary, the maximum mean values of $\mathrm{T}$ and $\mathrm{NH}_{4}{ }^{+}-\mathrm{N}$ were observed in summer and minimum presented in autumn.

Table 2. The seasonal variations (mean $\pm S E, n=32$ ) of environmental factors: water transparency (SD), depth (D), conductivity (COND), dissolved oxygen (DO), pH, water temperature (T), total nitrogen (TN), total phosphorus (TP), $N: P$ ratio $(N: P)$, ammonium nitrogen $\left(\mathrm{NH}_{4}{ }^{+}-\mathrm{N}\right)$, nitrate nitrogen $\left(\mathrm{NO}_{3}{ }^{-} \mathrm{N}\right)$, chemical oxygen demand $\left(\mathrm{COD}_{\mathrm{Mn}}\right)$ and dissolved iron $\left(\mathrm{Fe}^{3+}\right)$ and dissolved copper $\left(\mathrm{Cu}^{2+}\right), P$-value from One-way ANOVA and $a, b, c$ mean differences between the seasons were tested by post-hoc test using Tukey HSD ANOVA

\begin{tabular}{c|c|c|c|c}
\hline & Spring & Summer & Autumn & P-value \\
\hline $\mathrm{SD}(\mathrm{m})$ & $0.76 \pm 0.12^{\mathrm{a}}$ & $1.01 \pm 0.16^{\mathrm{b}}$ & $1.11 \pm 0.12^{\mathrm{b}}$ & 0.037 \\
$\mathrm{D}(\mathrm{m})$ & $8.48 \pm 3.26^{\mathrm{a}}$ & $10.93 \pm 3.99^{\mathrm{a}}$ & $10.57 \pm 3.70^{\mathrm{a}}$ & 0.716 \\
$\mathrm{COND}(\mathrm{ms} / \mathrm{cm})$ & $0.11 \pm 0.04^{\mathrm{a}}$ & $0.15 \pm 0.05^{\mathrm{a}}$ & $0.12 \pm 0.03^{\mathrm{a}}$ & 0.603 \\
$\mathrm{DO}(\mathrm{mg} / \mathrm{L})$ & $7.66 \pm 0.24^{\mathrm{a}}$ & $7.39 \pm 0.43^{\mathrm{a}}$ & $8.91 \pm 0.20^{\mathrm{b}}$ & 0.000 \\
$\mathrm{pH}$ & $7.44 \pm 0.10^{\mathrm{a}}$ & $7.17 \pm 0.15^{\mathrm{a}}$ & $7.80 \pm 0.10^{\mathrm{b}}$ & 0.000 \\
$\mathrm{~T}\left({ }^{\circ} \mathrm{C}\right)$ & $17.3 \pm 0.90^{\mathrm{a}}$ & $22.94 \pm 0.45^{\mathrm{b}}$ & $10.23 \pm 0.74^{\mathrm{c}}$ & 0.002 \\
$\mathrm{TN}(\mathrm{mg} / \mathrm{L})$ & $0.99 \pm 0.20^{\mathrm{a}}$ & $0.87 \pm 0.08^{\mathrm{a}}$ & $0.91 \pm 0.09^{\mathrm{a}}$ & 0.277 \\
$\mathrm{TP}(\mathrm{mg} / \mathrm{L})$ & $0.74 \pm 0.16^{\mathrm{a}}$ & $0.52 \pm 0.05^{\mathrm{ab}}$ & $0.36 \pm 0.06^{\mathrm{b}}$ & 0.002 \\
$\mathrm{~N}: \mathrm{P}$ & $1.97 \pm 0.67^{\mathrm{a}}$ & $1.67 \pm 0.04^{\mathrm{a}}$ & $2.92 \pm 0.56^{\mathrm{b}}$ & 0.005 \\
$\mathrm{NH}_{4}{ }^{-}-\mathrm{N}(\mathrm{mg} / \mathrm{L})$ & $0.13 \pm 0.01^{\mathrm{a}}$ & $0.23 \pm 0.04^{\mathrm{b}}$ & $0.12 \pm 0.02^{\mathrm{a}}$ & 0.000 \\
$\mathrm{NO}_{3}{ }^{-}-\mathrm{N}(\mathrm{mg} / \mathrm{L})$ & $0.36 \pm 0.06^{\mathrm{a}}$ & $0.28 \pm 0.07^{\mathrm{a}}$ & $0.20 \pm 0.05^{\mathrm{a}}$ & 0.069 \\
$\mathrm{COD}_{\mathrm{Mn}}(\mathrm{mg} / \mathrm{L})$ & $4.44 \pm 0.07^{\mathrm{a}}$ & $3.78 \pm 0.12^{\mathrm{b}}$ & $4.24 \pm 0.04^{\mathrm{a}}$ & 0.000 \\
$\mathrm{Fe}^{3+}(\mathrm{mg} / \mathrm{L})$ & $0.32 \pm 0.04^{\mathrm{a}}$ & $0.21 \pm 0.07^{\mathrm{b}}$ & $0.42 \pm 0.01^{\mathrm{a}}$ & 0.000 \\
$\mathrm{Cu}^{2+}(\mathrm{mg} / \mathrm{L})$ & $0.21 \pm 0.04^{\mathrm{a}}$ & $0.16 \pm 0.03^{\mathrm{a}}$ & $0.03 \pm 0.01^{\mathrm{b}}$ & 0.000 \\
\hline
\end{tabular}




\section{Variation of zooplankton functional groups in Tuanjie Reservoir}

A total of 30 zooplankton species belonging to 25 genera and four taxonomic groups including protozoa $(33.33 \%)$, rotifera $(36.67 \%)$, cladoceran $(16.67 \%)$ and copepods $(13.33 \%)$ were identified in the Tuanjie Reservoir (Table 3). The biomass of zooplankton functional groups showed seasonal and spatial variation (Figs. 2 and 3). Summer recorded the highest number of zooplankton species (20) followed by spring (19) and autumn (17). In summer, the dominant zooplankton functional group was PF mainly comprised by Paramecium (43.81\%) and Didinium nasutum (37.55\%), and RF which was presented by Keratella cochlearis $(3.27 \%)$ and Polyarthra trigla $(2.03 \%)$. While in spring, the dominant zooplankton functional group PF was presented only by Paramecium (74\%). In autumn, the dominant zooplankton functional group PF was contributed by Paramecium (44.82\%) and that of group RF was Keratella cochlearis $(26.89 \%)$.

Table 3. Zooplankton functional groups and biomass (\%) in Tuanjie Reservoir, PF (protozoa filter feeders), RF (rotifera filter feeders), SCF (small copepods and cladoceran filter feeders), MCC (middle copepods and cladoceran carnivore), MCF (middle copepods and cladoceran filter feeders), LCC (large copepods and cladoceran carnivore), LCF (large copepod filter feeders)

\begin{tabular}{|c|c|c|c|c|c|}
\hline Taxonomic group & Species & Functional groups & Spring & Summer & Autumn \\
\hline \multirow{10}{*}{ Protozoa } & Lagynophrya conifera & $\mathrm{PF}$ & 2.43 & - & - \\
\hline & Strombidium viride & $\mathrm{PF}$ & 2.97 & - & 2.79 \\
\hline & Strobilidium velox & $\mathrm{PF}$ & 1.35 & 1.88 & 2.69 \\
\hline & Strobilidium gyrans & $\mathrm{PF}$ & 0.72 & - & - \\
\hline & Tetrahymena priformis & $\mathrm{PF}$ & 3.67 & 0.69 & 1.61 \\
\hline & Vorticella campanula & $\mathrm{PF}$ & 0.46 & 0.88 & 1.26 \\
\hline & Paramecium sp. & $\mathrm{PF}$ & 74.00 & 43.81 & 44.82 \\
\hline & Didinium balbianii nanum & $\mathrm{PF}$ & 4.49 & - & - \\
\hline & Didinium nasutum & $\mathrm{PF}$ & - & 37.55 & - \\
\hline & Difflugia avellana & $\mathrm{PF}$ & 0.60 & - & - \\
\hline \multirow{11}{*}{ Rotifera } & Polyarthra trigla & $\mathrm{RF}$ & 2.47 & 2.03 & 4.55 \\
\hline & Filinia longiseta & $\mathrm{RF}$ & 0.50 & - & - \\
\hline & Keratella cochlearis & $\mathrm{RF}$ & - & 3.27 & 26.89 \\
\hline & Keratella quadrata & $\mathrm{RF}$ & 2.34 & - & - \\
\hline & Trichocerca Lamarck & RF & 1.05 & 1.20 & 2.90 \\
\hline & Trichocerca porcellus & RF & - & 0.21 & - \\
\hline & Lecane luna & $\mathrm{RF}$ & 1.78 & - & - \\
\hline & Lecane tenuiseta Harring & $\mathrm{RF}$ & - & 1.77 & - \\
\hline & Pompholyx sulcata Hudson & $\mathrm{RF}$ & - & 0.55 & - \\
\hline & Colurella uncinata & $\mathrm{RF}$ & - & 0.08 & - \\
\hline & Brachionus diversicornis & $\mathrm{RF}$ & - & 0.96 & - \\
\hline \multirow{5}{*}{ Cladoceran } & Bosmina longirostris & SCF & 0.43 & - & 0.05 \\
\hline & Diaphanosoma leuchtenbergianum & $\mathrm{MCF}$ & - & - & 1.21 \\
\hline & Leptodora kindti & LCC & - & 0.05 & 0.44 \\
\hline & Daphnia cristata Sars & SCF & - & 0.13 & 1.09 \\
\hline & Daphnia magna & $\mathrm{MCF}$ & - & 4.09 & 7.24 \\
\hline \multirow{4}{*}{ Copepoda } & Cyclops strenuns & $\mathrm{MCC}$ & 0.26 & 0.35 & 0.60 \\
\hline & Calanioda.sp & LCF & 0.12 & 0.16 & 0.45 \\
\hline & Thermocyclops dybowskii & MCC & 0.19 & 0.25 & 1.00 \\
\hline & Microcyclops javanus & SCF & 0.18 & 0.09 & 0.41 \\
\hline
\end{tabular}



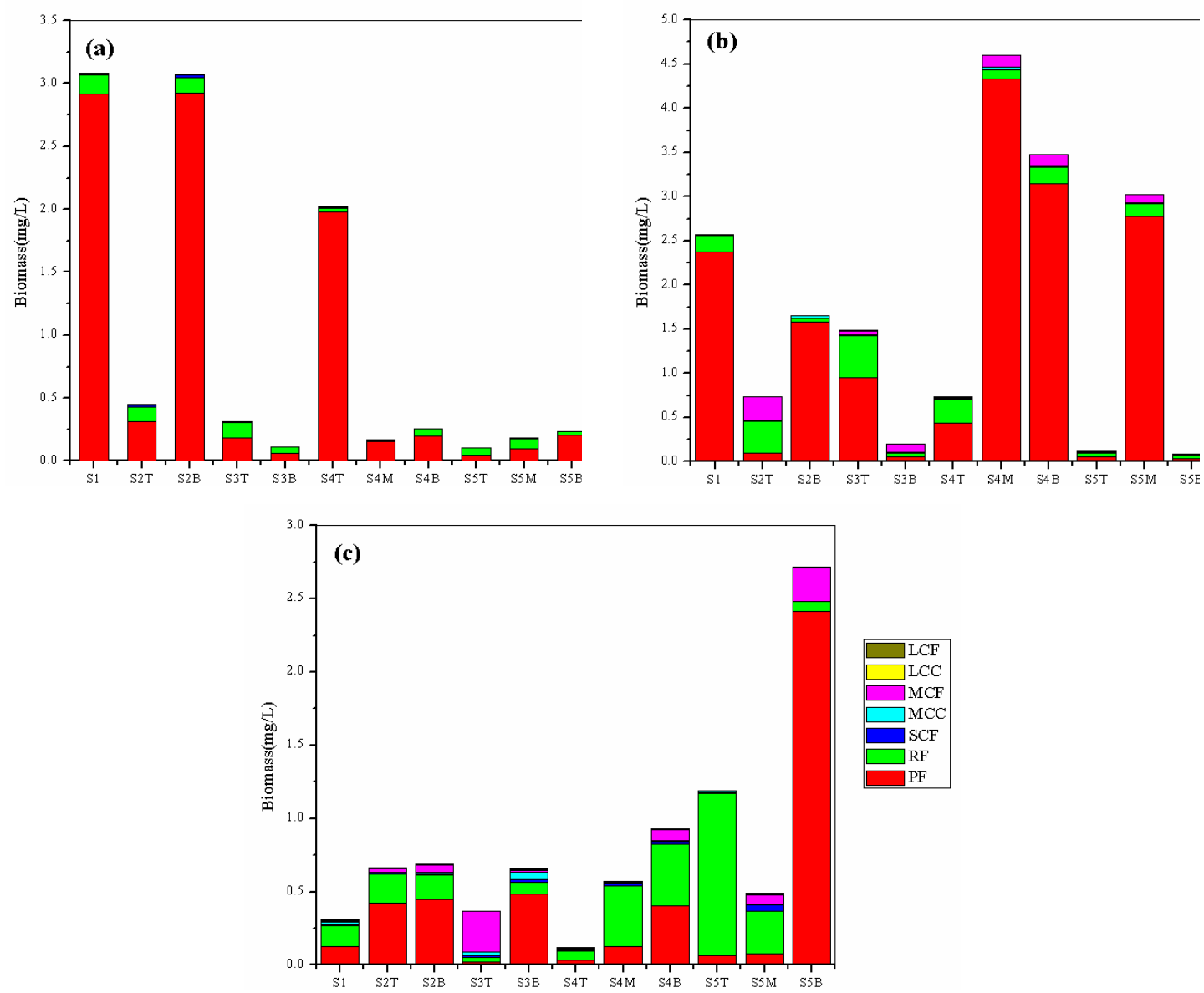

Figure 2. Zooplankton functional group biomass of spring (a), summer (b) and autumn (c), S2T (Sampling site 2 top water layer), S4M (Sampling site 4 middle water layer), S2B (Sampling site

2 bottom water layer), $P F$ (protozoa filter feeders), RF (rotifera filter feeders), SCF (small copepods and cladoceran filter feeders), MCC (middle copepods and cladoceran carnivore), MCF (middle copepods and cladoceran filter feeders), LCC (large copepods and cladoceran carnivore), LCF (large copepod filter feeders)
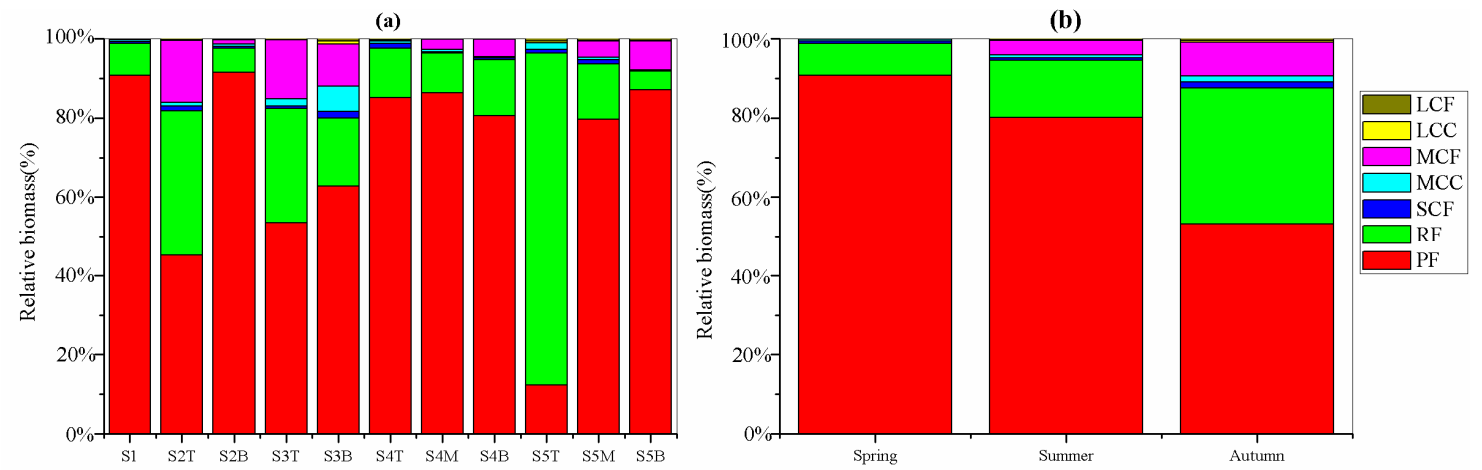

Figure 3. Relative biomass of zooplankton functional groups among sampling sites (a) and seasons (b), S2T (Sampling site 2 top water layer), S4M (Sampling site 4 middle water layer),

$S 2 B$ (Sampling site 2 bottom water layer), PF (protozoa filter feeders), RF (rotifera filter feeders), SCF (small copepods and cladoceran filter feeders), MCC (middle copepods and cladoceran carnivore), MCF (middle copepods and cladoceran filter feeders), LCC (large copepods and cladoceran carnivore), LCF (large copepod filter feeders) 


\section{Correlation of zooplankton functional groups and environmental factors}

The Spearman correlation analysis of zooplankton functional group biomass and environmental factors were listed in Tables 4 and 5, respectively. Group PF influenced RF, and group LCC influenced SCF and LCF. The feeding relationship of zooplankton functional groups has been proved by the results. Meanwhile, most environmental factors were correlated with zooplankton functional groups. Like group LCC, was significantly influenced by SD $(r=0.374), \mathrm{T}(r=0.347), \mathrm{NH}_{4}{ }^{+}-\mathrm{N}(r=0.494)$ and $\mathrm{COD}_{\mathrm{Mn}}(r=-0.541)$. Groups MCF was negatively correlated with $\mathrm{NO}_{3}{ }^{-} \mathrm{N}(r=-0.419)$ and $\mathrm{COD}_{\mathrm{Mn}}(r=-0.541)$. Other side, COND was positively correlated with group PF $(r=0.407)$, RF $(r=0.392)$ and SCF $(r=0.477)$. However, the $\mathrm{DO}$ and $\mathrm{NH}_{4}{ }^{+}-\mathrm{N}$ was only significant positively correlated with group MCC $(r=0.386)$ and LCF $(r=0.410)$ respectively.

Table 4. Spearman correlation of zooplankton functional group biomass. PF (protozoa filter feeders), RF (rotifera filter feeders), SCF (small copepods and cladoceran filter feeders), MCC (middle copepods and cladoceran carnivore), MCF (middle copepods and cladoceran filter feeders), LCC (large copepods and cladoceran carnivore), LCF (large copepod filter feeders)

\begin{tabular}{c|c|c|c|c|c|c|c}
\hline & PF & RF & SCF & MCC & MCF & LCC & LCF \\
\hline PF & 1 & .253 & .112 & .010 & .080 & -.044 & .071 \\
$\mathrm{RF}$ & .253 & 1 & .313 & .197 & $.344^{*}$ & .296 & .035 \\
$\mathrm{SCF}$ & .112 & .313 & 1 & .178 & .065 & $.421^{*}$ & .225 \\
$\mathrm{MCC}$ & .010 & .197 & .178 & 1 & .273 & .261 & -.100 \\
$\mathrm{MCF}$ & .080 & $.344^{*}$ & .065 & .273 & 1 & .340 & .011 \\
$\mathrm{LCC}$ & -.044 & .296 & $.421^{*}$ & .261 & .340 & 1 & $.356^{*}$ \\
$\mathrm{LCF}$ & .071 & .035 & .225 & -.100 & .011 & $.356^{*}$ & 1 \\
\hline
\end{tabular}

${ }^{* *} p<0.01,{ }^{*} p<0.05$

Table 5. Spearman correlation between zooplankton functional group biomass and environmental factors, water transparency (SD), depth (D), conductivity (COND), dissolved oxygen (DO), $p H$, water temperature (T), total nitrogen (TN), total phosphorus (TP), N:P ratio (N:P), ammonium nitrogen $\left(\mathrm{NH}_{4}{ }^{+}-\mathrm{N}\right)$, nitrate nitrogen $\left(\mathrm{NO}_{3}{ }^{-}-\mathrm{N}\right)$, chemical oxygen demand $\left(\mathrm{COD}_{\mathrm{Mn}}\right)$ and dissolved iron $\left(\mathrm{Fe}^{3+}\right)$ and dissolved copper $\left(\mathrm{Cu}^{2+}\right)$. PF (protozoa filter feeders), RF (rotifera filter feeders), SCF (small copepods and cladoceran filter feeders), $M C C$ (middle copepods and cladoceran carnivore), MCF (middle copepods and cladoceran filter feeders), LCC (large copepods and cladoceran carnivore), LCF (large copepod filter feeders)

\begin{tabular}{c|c|c|c|c|c|c|c|c|c|c|c|c|c|c}
\hline & SD & $\mathbf{D}$ & $\mathbf{C O N D}$ & $\mathbf{D O}$ & $\mathbf{p H}$ & $\mathbf{T}$ & $\mathbf{T N}$ & $\mathbf{T P}$ & $\mathbf{N}: \mathbf{P}$ & $\mathbf{N H}_{4}{ }^{+} \mathbf{- N}$ & $\mathbf{N O}_{3}{ }^{-} \mathbf{N}$ & $\mathbf{C O D}_{\mathbf{M n}}$ & $\mathbf{F e}^{3+}$ & $\mathbf{C u}^{\mathbf{2}^{+}}$ \\
\hline PF & -.075 & .121 & $.407^{*}$ & .152 & .302 & -.178 & .040 & -.074 & .041 & -.272 & -.157 & .220 & .164 & -.050 \\
RF & .099 & -.154 & $.392^{*}$ & -.126 & .095 & .102 & .100 & -.109 & -.050 & .196 & -.119 & -.306 & -.021 & -.137 \\
SCF & -.004 & -.179 & $.477^{* *}$ & -.247 & -.201 & .262 & -.061 & -.068 & -.086 & .149 & .034 & -.147 & -.286 & .140 \\
MCC & -.011 & -.332 & .007 & $.386^{*}$ & .189 & -.092 & .083 & -.017 & .038 & -.125 & -.149 & -.294 & .257 & -.291 \\
MCF & .339 & .174 & .182 & -.015 & .049 & .107 & -.144 & .032 & -.203 & .067 & $-.419^{*}$ & $-.541^{* *}$ & -.133 & -.262 \\
LCC & $.374^{*}$ & .160 & .148 & -.312 & -.193 & $.347^{*}$ & -.171 & .031 & -.187 & $.494^{* *}$ & -.160 & $-.541^{* *}$ & -.324 & -.013 \\
LCF & .209 & -.071 & -.033 & -.128 & -.118 & -.052 & -.054 & -.153 & .154 & $.410^{*}$ & .179 & .089 & .122 & -.048 \\
\hline
\end{tabular}




\section{$R D A$ analysis between zooplankton functional groups and environmental factors}

The results of Monte Carlo test showed that the first canonical axis and all canonical axes were significant $(F=13.521, p=0.002 ; F=1.130, p=0.002 ; 499$ random permutations). The eigenvalues of the four axes were $0.429,0.033,0.015,0.004$, respectively (Table 6 ). The functional groups-environment correlations for Axis 1 and Axis 2 were 0.686 and 0.691 , respectively. The first two axes account for $46.2 \%$ of functional groups-environment variables relation (axis 1: 42.9\%, axis 2: $3.3 \%$ ) and $98.8 \%$ of the functional groups variables (axis 1: 91.7\%, axis 2: 7.1\%). Axis 1 was mainly positive correlated with $\mathrm{pH}(r=0.728)$ and $\mathrm{DO}(r=0.683)$ and negatively correlated with $\mathrm{T}(r=-0.672)$. Axis 2 was positively correlated with $\mathrm{NH}_{4}{ }^{+}-\mathrm{N}$ $(r=0.602)$, SD $(r=0.481)$ and negatively correlated with $\operatorname{COD}_{\mathrm{Mn}}(r=-0.658)$, $\mathrm{Fe}^{3+}(r=-0.501)$. Groups PF was positively related with $\mathrm{pH}$, COND and $\mathrm{COD}_{\mathrm{Mn}}$, and negatively related with $\mathrm{T}, \mathrm{NH}_{4}{ }^{+}-\mathrm{N}, \mathrm{NO}_{3}{ }^{-}-\mathrm{N}$ and $\mathrm{Cu}^{2+}$. Group RF, SCF, MCF, LCF and LCC were positively related with $\mathrm{NH}_{4}{ }^{+}-\mathrm{N}$ and $\mathrm{SD}$, and negatively related with $\mathrm{COD}_{\mathrm{Mn}}$, $\mathrm{Fe}^{3+}, \mathrm{DO}, \mathrm{Cu}^{2+}$ and $\mathrm{NO}_{3}{ }^{-} \mathrm{N}$. Nevertheless, the group $\mathrm{MCC}$ was not related with most of environmental factors (Fig. 4).

Table 6. $R D A$ results of zooplankton functional group biomass

\begin{tabular}{c|c|c|c|c}
\hline Axes & Eigenvalues & $\begin{array}{c}\text { Species- } \\
\text { environment } \\
\text { correlations }\end{array}$ & $\begin{array}{c}\text { Cumulative percentage } \\
\text { variance of species data }\end{array}$ & $\begin{array}{c}\text { Cumulative percentage } \\
\text { variance of species- } \\
\text { environment relation }\end{array}$ \\
\hline 1 & 0.429 & 0.686 & 42.9 & 91.7 \\
2 & 0.033 & 0.691 & 46.2 & 98.8 \\
3 & 0.015 & 0.563 & 46.8 & 100 \\
4 & 0.004 & 0.468 & 46.8 & 100 \\
\hline
\end{tabular}

\section{Discussion}

Zooplankton, as an important part of the food chain in the aquatic ecosystem, is mainly composed of free-living protozoa, rotifera, cladocera and copepod. Zooplankton is very sensitive to environmental changes and hence considered as good indicator. Many previous studies focused on zooplankton community structure in relation to environmental factors (Bachiller et al., 2018; Coz et al., 2018; Jeppesen et al., 2011; Li et al., 2014; Matsuzaki et al., 2018; Neumann-Leitão et al., 2018). Recently, using functional groups to reveal the reaction of environmental factors are considered as a new method (Ma et al., 2019; Mwagona et al., 2018; Shi et al., 2015; Sun et al., 2010). Functional groups are species with similar morphological and physiological traits (Reynolds et al., 2002). In marine ecosystems, six functional groups have been classified according to zooplankton species individual size and feeding habits from the yellow sea (Sun et al., 2010). In Western English channel, the researchers analyzed the food web using three zooplankton functional groups (Araújo et al., 2006). On the other hand, in freshwater ecosystems, six and eight zooplankton functional groups have been confirmed in Small Xingkai Wetland Lake and Xiquanyan Reservoir in Heilongjiang Province, Northeast of China, respectively (Ma et al., 2019; Mwagona et al., 2018). In our study, we identified 30 species belonging to seven zooplankton functional groups in Tuanjie Reservoir, including group PF, RF, SCF, MCC, MCF, LCC and LCF. 


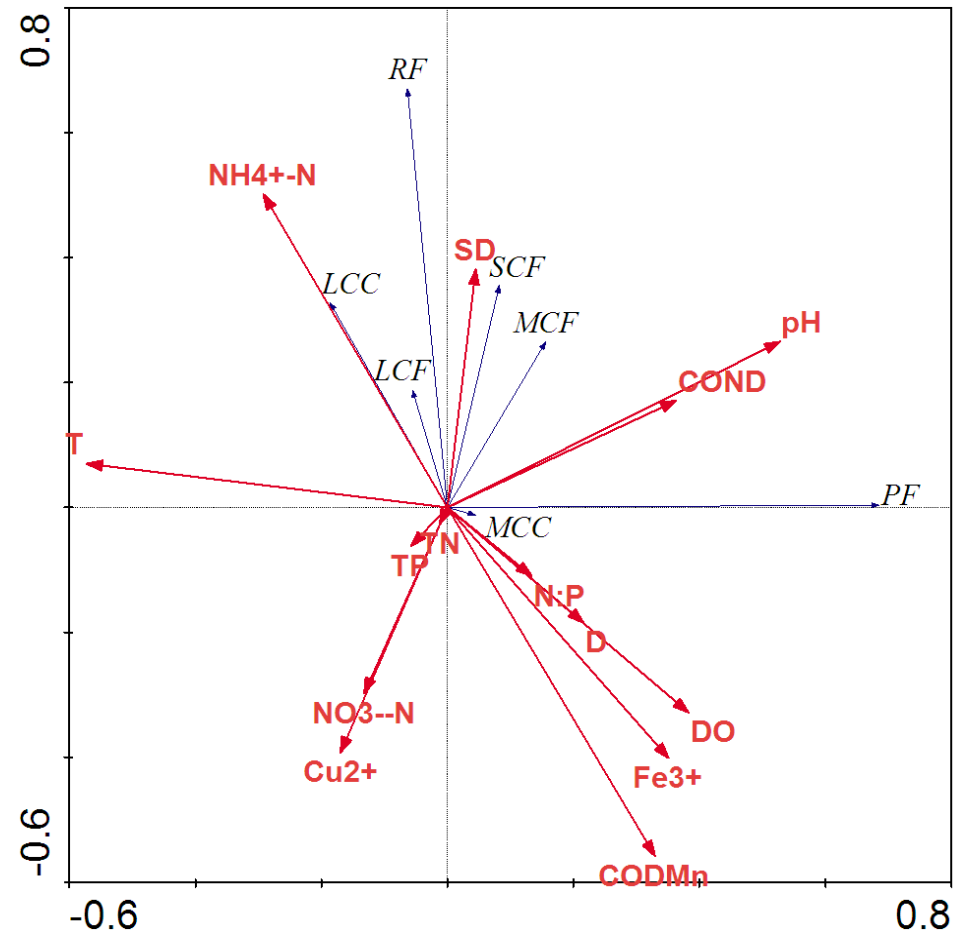

Figure 4. RDA bioplot of zooplankton functional groups and environmental factors, water transparency (SD), depth (D), conductivity (COND), dissolved oxygen (DO), pH, water temperature (T), total nitrogen (TN), total phosphorus (TP), N:P ratio (N:P), ammonium nitrogen $\left(\mathrm{NH}_{4}{ }^{+}-\mathrm{N}\right)$, nitrate nitrogen $\left(\mathrm{NO}_{3}{ }^{-}-\mathrm{N}\right)$, chemical oxygen demand $\left(\mathrm{COD}_{\mathrm{Mn}}\right)$ and dissolved iron $\left(\mathrm{Fe}^{3+}\right)$ and dissolved copper $\left(\mathrm{Cu}^{2+}\right)$. PF (protozoa filter feeders), $\mathrm{RF}$ (rotifera filter feeders), SCF (small copepods and cladoceran filter feeders), MCC (middle copepods and cladoceran carnivore), MCF (middle copepods and cladoceran filter feeders), LCC (large copepods and cladoceran carnivore), LCF (large copepod filter feeders)

\section{Composition and variations of zooplankton functional groups in Tuanjie Reservoir}

Seasonal and spatial variations of zooplankton biomass were demonstrated in aquatic ecosystems by Dube et al. (2017). In this study, the biomass of zooplankton functional groups varied significantly differences among seasons and sites. The mean values of biomass reported in spring $(0.91 \mathrm{mg} / \mathrm{L})$, summer $(1.70 \mathrm{mg} / \mathrm{L})$ and autumn $(0.79 \mathrm{mg} / \mathrm{L})$ were higher than those recorded by Mwagona et al. (2018) in the oligotrophic Xiquanyan Reservoir during spring $(54.25 \mu \mathrm{g} / \mathrm{L})$, summer $(245.81 \mu \mathrm{g} / \mathrm{L})$ and autumn $(196.54 \mu \mathrm{g} / \mathrm{L})$ and also higher than those found by Ma et al. (2019) in Small Xingkai Lake during spring $(0.28 \mathrm{mg} / \mathrm{L})$ and autumn $(0.72 \mathrm{mg} / \mathrm{L})$ in the same province. Mwagona et al. (2018) found that low nutrients level, which unable to meet the demand of the growth of zooplankton. While, Ma et al. (2019) noted that nutrient-rich level could promote the zooplankton breeding, and high turbid with low transparency also may contribute to zooplankton avoid predators.

As shown in Figure 2, during spring and summer seasons, zooplankton biomass was both dominated by protozoa filter feeders (group PF) accounting for $90.68 \%$ and $84.8 \%$ of total biomass, respectively. In spring, group PF mainly composed of Paramecium $\mathrm{sp}$. (74\%), while in summer mainly composed of Paramecium sp. (43.81\%) and Didinium nasutum (37.55\%). Group PF (protozoa filter feeders) are filter feeding on bacteria, algae and organic detritus and found in all sampling sites and water layer. We found 
that the biomass of group PF in summer was significantly higher than that in spring probably due to higher temperature and nutrients contributed to algae growth of their food resources (Duggan et al., 2001; Špoljar et al., 2010), and higher water transparency help them locate prey more clearly and predation activities more easily (Ma et al., 2019). Besides, Didinium nasutum could use their flagella enhance swimming ability in favor of avoiding predators and harvesting suitable light and food for growth, therefore became an dominant species (Bovo-Scomparin and Train, 2008). In autumn, zooplankton biomass was dominated by protozoa filter feeders (group PF) and rotifera filter feeders (group RF) accounted for $53.17 \%$ and $34.34 \%$ of total biomass, respectively. Group PF mainly composed of Paramecium sp. (44.82\%) and group RF mainly composed of Keratella cochlearis (26.89\%). This could be due to higher temperature in summer was suitable for rotifera breeding in large numbers (Galkovskaja, 1987), so they formed a dominant species in autumn. Another reason could be some environmental factors such as nutrients and turbidity can influence rotifera community structure in autumn (Armengol et al., 1998; Ma et al., 2019), and finally, it leads to the change of the structure and composition of zooplankton community. Moreover, other zooplankton functional groups preyed by their predators such as Hypophthalmichthys molitrix and Aristichthys nobilis, and some competitive interactions between those functional groups lead to relative low biomass among sampling sites and seasons in the reservoir during study (Fig. $3 a$ and $b$ ).

\section{Driving factors of zooplankton functional groups in Tuanjie Reservoir}

There are so many driving factors influence the zooplankton community structure in aquatic ecosystems (Li et al., 2014; Ma et al., 2019; Mwagona et al., 2018; Shi et al., 2015; Sun et al., 2010). Among zooplankton functional groups, group MCF was positively correlated with group RF, and group LCC were both positively correlated with group SCF and LCF, which could due to intraspecific competition (Table 4). However, between environment and zooplankton, water depth did not affect the distribution of zooplankton functional groups (Table 5). Similarly, there was seemingly no significant variation in the abundance patterns of the dominant zooplankton taxa in response to changing $\mathrm{pH}$ value (Morgan, 1985a). The Spearman correlation results showed that $\mathrm{pH}$ was not related with the biomass of zooplankton functional groups in Tuanjie Reservoir (Table 5). The fluctuation of $\mathrm{pH}$ value in the freshwater ecosystem was primarily the result of enhanced primary productivity (Morgan, 1985b). Further studies also proved that the density of zooplankton individuals is influenced by the primary producers phytoplankton biomass (Trevisan and Forsberg, 2007).

On the other hand, this present study showing that nitrogen and phosphorus can usually be considered the main limiting nutrient (Fasham et al., 1990; Shumka et al., 2018). While in our study, both Spearman correlation and RDA results showing that the zooplankton functional groups were not affected by TN, TP and N:P ratio in Tuanjie Reservoir (Table 5; Fig. 4). That could be due to trophic level weakened their effect on plankton community in the reservoir, because an increase in trophic state can caused an increase in the total numbers of crustaceans (Ejsmont-Karabin and Karabin, 2013). The Spearman correlation and RDA results both showed that $\mathrm{NH}_{4}{ }^{+}-\mathrm{N}$ was positively influence group LCC and $\mathrm{LCF}$, and $\mathrm{NO}_{3}{ }^{-}-\mathrm{N}$ was negatively influence group MCF (Table 5; Fig. 4).

Metallic element concentrations were strongly correlated with plankton structure and biomass composition (Long et al., 2018). Such as iron (Fe) considered as important 
nutrient affecting the growth of phytoplankton (Alderkamp et al., 2015). Some phytoplankton species can take up Fe through their specialized transport mechanisms (Morel et al., 2008). Some researchers also found that zooplankton could directly obtain enough $\mathrm{Fe}$ to maintain growth (Baines et al., 2016). Similarly, copper (Cu) plays an important role in the physiology of natural plankton communities (Semeniuk et al., 2009). In Tuanjie Reservoir, there was no relationship among metal ion $\left(\mathrm{Fe}^{3+}, \mathrm{Cu}^{2+}\right)$ with the biomass of zooplankton functional groups, which results consistent with RDA (Table 5, Fig. 4). We suspect that could be the zooplankton functional groups affected by the top-down and bottom-up control in the food webs (Carvalho, 1994; Prowe et al., 2012; Sinistro, 2010; Stephen, 2010; Sun et al., 2013). This proof confirmed a complex interaction between $\mathrm{Fe}$ and $\mathrm{Cu}$ physiology in plankton communities (Semeniuk et al., 2016). Besides, the primary correlated factors included chlorophyll a levels, cyanobacterial toxin levels, and temperature, suggesting that both phytoplankton biomass and composition play important roles in zooplankton dynamics (Srifa, 2010).

In addition, turbulence and turbidity of water column intensified the competition among zooplankton species (Zhou et al., 2018). These environmental factors should be considered as the new influencing variables in Tuanjie Reservoir for further studies in the future.

\section{Conclusion}

In this study, a total of 30 zooplankton species belonging to protozoa, rotifera, cladoceran and copepod were identified and classified into seven functional groups including PF, RF, SCF, MCC, MCF, LCC and LCF. Both environmental factors and zooplankton functional groups biomass in Tuanjie Reservoir varied seasonally and spatially. $\mathrm{SD}, \mathrm{DO}, \mathrm{pH}, \mathrm{N}: \mathrm{P}$ and $\mathrm{Fe}^{3+}$ were significant higher in autumn, while $\mathrm{TP}$ and $\mathrm{T}$ was higher in spring and summer. Zooplankton functional group biomass was higher in summer $(0.62 \mathrm{mg} / \mathrm{L})$, followed by spring $(0.33 \mathrm{mg} / \mathrm{L})$ and autumn $(0.29 \mathrm{mg} / \mathrm{L})$. In spring group PF was the dominant functional group, while in summer and autumn group $\mathrm{PF}$ and RF were both the dominant functional group. SD, COND, DO, $\mathrm{NH}_{4}{ }^{+}-\mathrm{N}, \mathrm{NO}_{3}{ }^{-}-\mathrm{N}$ and $\mathrm{COD}_{\mathrm{Mn}}$ considered as the major factors influence zooplankton functional groups in Tuanjie Reservoir. Group PF was positively correlated with $\mathrm{pH}$ and COND while negatively correlated with T. Groups RF, SCF and LCC were positively influenced by $\mathrm{NH}_{4}{ }^{+}-\mathrm{N}$ and $\mathrm{SD}$, while negatively influenced by $\mathrm{COD}_{\mathrm{Mn}}, \mathrm{Fe}^{3+}, \mathrm{DO}, \mathrm{Cu}^{2+}$ and $\mathrm{NO}_{3}{ }^{-}-\mathrm{N}$.

Acknowledgements. We thank to the leaders and workers from Muling city Fendou Reservoir construction headquarters for their assistance and support during field sampling work. The study was supported by programs of the National Key Research and Development Program of China (Grant No. 2016YFC0500406).

\section{REFERENCES}

[1] Alderkamp, A. C., Dijken, G. L. V., Lowry, K. E., Connelly, T. L., Lagerström, M., Sherrell, R. M., Haskins, C., Rogalsky, E., Schofield, O., Stammerjohn, S. E., Yager, P. L., Arrigo, K. R. (2015): Fe availability drives phytoplankton photosynthesis rates during spring bloom in the Amundsen Sea Polynya, Antarctica. - Elementa: Science of the Anthropocene 3: 1-26. 
[2] Anderson, T. (2005): Plankton functional type modelling: running before we can walk? Journal of Plankton Research 27: 1073-1081.

[3] Araújo, J. N., Mackinson, S., Stanford, R. J., Sims, D. W., Southward, A. J., Hawkins, S. J., Ellis, J. R., Hart, P. J. B. (2006): Modelling food web interactions, variation in plankton production, and fisheries in the western English Channel ecosystem. - Marine Ecology Progress Series 309: 175-187.

[4] Armengol, X., Esparcia, A., Miracle, M. R. (1998): Rotifera vertical distribution in a strongly stratified lake: a multivariate analysis. - Hydrobiologia 387-388: 161-170.

[5] Bachiller, E., Utne, K. R., Jansen, T., Huse, G. (2018): Bioenergetics modeling of the annual consumption of zooplankton by pelagic fish feeding in the Northeast Atlantic. Plos One 13: e0190345-.

[6] Baines, S. B., Chen, X., Twining, B. S., Fisher, N. S., Landry, M. R. (2016): Factors affecting Fe and $\mathrm{Zn}$ contents of mesozooplankton from the Costa Rica Dome. - Journal of Plankton Research 38: 331-347.

[7] Beaugrand, G., Ibañez, F., Reid, P. C. (2000): Spatial, seasonal and long-term fluctuations of plankton in relation to hydroclimatic features in the English Channel, Celtic Sea and Bay of Biscay. - Marine Ecology Progress Series 200: 93-102.

[8] Benedetti, F., Vogt, M., Righetti, D., Guilhaumon, F., Ayata, S. D. (2018): Do functional groups of planktonic copepods differ in their ecological niches? - Journal of Biogeography. https://doi.org/10.1111/jbi.13166.

[9] Bovo-Scomparin, V. M., Train, S. (2008): Long-term variability of the phytoplankton community in an isolated floodplain lake of the Ivinhema River State Park, Brazil. Hydrobiologia 610(1): 331-344.

[10] Carvalho, L. (1994): Top-down control of phytoplankton in a shallow hypertrophic lake: Little Mere (England). - Hydrobiologia 275-276: 53-63.

[11] Chen, Q. C. (1974): On planktonic copepods of the Yellow Sea and the East China Sea, II. Cyclopoida and Harpacticoida. - Studia Marina Sinica 9: 1-24.

[12] Chiang, S. C., Du, N. S. (1979): Fauna Sinica, Crustacea, Freshwater Cladocera. Science Press, Beijing.

[13] Coz, M. L., Chambord, S., Souissi, S., Meire, P., Ovaert, J., Buffan-Dubau, E., Prygiel, J., Azémar, F., Sossou, A. C., Lamothe, S. (2018): Are zooplankton communities structured by taxa ecological niches or by hydrological features? - Ecohydrology: e1956.

[14] David, V., Sautour, B., Chardy, P., Leconte, M. (2005): Long-term changes of the zooplankton variability in a turbid environment: the Gironde estuary (France). Estuarine, Coastal and Shelf Science 64: 171-184.

[15] Dube, T., Denecker, L., Vuren, J. H. J. V., Wepener, V., Smit, N. J., Brendonck, L. (2017): Spatial and temporal variation of invertebrate community structure in floodcontrolled tropical floodplain wetlands. - Journal of Freshwater Ecology 32: 1-15.

[16] Duggan, I. C., Green, J. D., Shiel, R. J. (2001): Distribution of rotiferas in north island, new zealand, and their potential use as bioindicators of lake trophic state. Hydrobiologia 446/447: 155-164.

[17] Ejsmont-Karabin, J., Karabin, A. (2013): The suitability of zooplankton as lake ecosystemindicators: crustacean trophic state index. - Polish Journal of Ecology 61: 561573.

[18] Fasham, M. J. R., Ducklow, H. W., Mckelvie, S. M. (1990): A nitrogen-based model of plankton dynamics in the oceanic mixed layer. - Journal of Marine Research 48: 591639.

[19] Galkovskaja, G. A. (1987): Planktonic rotiferas and temperature. - Hydrobiologia 147: 307-317.

[20] Hood, R. R., Laws, E. A., Armstrong, R. A., Bates, N. R., Brown, C. W., Carlson, C. A., Chai, F., Doney, S. C., Falkowski, P. G., Feely, R. A. (2006): Pelagic functional group modeling: progress, challenges and prospects. - Deep-Sea Research Part II 53: 459-512. 
[21] Jeppesen, E., Jensen, J. P., Jensen, C., Faafeng, B., Hessen, D. O., Søndergaard, M., Lauridsen, T., Brettum, P., Christoffersen, K. (2003): The impact of nutrient state and lake depth on top-down control in the pelagic zone of lakes: a study of 466 lakes from the temperate zone to the Arctic. - Ecosystems 6: 313-325.

[22] Jeppesen, E., Nõges, P., Davidson, T. A., Haberman, J., Nõges, T., Blank, K., Amsinck, S. L. (2011): Zooplankton as indicators in lakes: a scientific-based plea for including zooplankton in the ecological quality assessment of lakes according to the European Water Framework Directive (WFD). - Hydrobiologia 676: 279-297.

[23] Li, X. Y., Yu, H. X., Ma, C. X. (2014): Zooplankton community structure in relation to environmental factors and ecological assessment of water quality in the Harbin Section of the Songhua River. - Chinese Journal of Oceanology \& Limnology 32: 1344-1351.

[24] Lobry, J., David, V., Pasquaud, S., Lepage, M., Sautour, B., Rochard, E. (2008): Diversity and stability of an estuarine trophic network. - Marine Ecology Progress Series 358: $13-25$.

[25] Long, S. X., Hamilton, P. B., Yang, Y., Wang, S., Huang, W. D., Chen, C., Ran, T. (2018): Differential bioaccumulation of mercury by zooplankton taxa in a mercurycontaminated reservoir Guizhou China. - Environmental Pollution 239: 147-160.

[26] Ma, C. X., Mwagona, P. C., Yu, H. X., Sun, X. W., Liang, L. Q. (2019): Seasonal dynamics of zooplankton functional group and its relationship with physicochemical variables in high turbid nutrient-rich Small Xingkai Wetland Lake, Northeast China. Journal of Freshwater Ecology 34: 65-79.

[27] Matsuzaki, S. S., Suzuki, K., Kadoya, T., Nakagawa, M., Takamura, N. (2018): Bottomup linkages between primary production, zooplankton, and fish in a shallow, hypereutrophic lake. - Ecology.

[28] MEP (2002): China national environmental quality standards for surface water. GB3838-2002 (in Chinese).

[29] Morel, F. M. M., Kustka, A. B., Shaked, Y. (2008): The role of unchelated Fe in the iron nutrition of phytoplankton. - Limnology and Oceanography 53: 400-404.

[30] Morgan, M. D. (1985a): The effect of altered $\mathrm{pH}$ on zooplankton community structure in a disturbed New Jersey pine barrens pond. - Journal of Freshwater Ecology 3: 467-476.

[31] Morgan, M. D. (1985b): Photosynthetically elevated $\mathrm{pH}$ in acid waters with high nutrient content and its significance for the zooplankton community. - Hydrobiologia 128: 239247.

[32] Mwagona, P. C., Ma, C. X., Yu, H. X. (2018): Seasonal dynamics of Zooplankton functional groups in relation to environmental variables in Xiquanyan Reservoir, Northeast China. - Annales de Limnologie-International Journal of Limnology 54: 33.

[33] Neumann-Leitão, S., Melo, P. A. M. C., Schwamborn, R., Diaz, X. F. G., Figueiredo, L. G. P., Silva, A. P., Campelo, R. P. S., Júnior, M. D. M., Melo, N. F. A. C., Costa, A. E. S. F. (2018): Zooplankton from a reef system under the influence of the Amazon River plume. - Frontiers in Microbiology 9: 1-15.

[34] Prowe, A. E. F., Pahlow, M., Dutkiewicz, S., Follows, M., Oschlies, A. (2012): Topdown control of marine phytoplankton diversity in a global ecosystem model. - Progress in Oceanography 101: 1-13.

[35] Quéré, C. L., Harrison, S. P., Prentice, I. C., Buitenhuis, E. T., Aumont, O., Bopp, L., Claustre, H., Cunha, L. C. D., Geider, R., Giraud, X. (2010): Ecosystem dynamics based on plankton functional types for global ocean biogeochemistry models. - Global Change Biology 11: 2016-2040.

[36] Reynolds, C. S., Huszar, V., Kruk, C., NaselliFlores, L., Melo, S. (2002): Towards a functional classification of the freshwater phytoplankton. - Journal of Plankton Research 24: 417-428.

[37] Semeniuk, D. M., Cullen, J. T., Johnson, W. K., Gagnon, K., Ruth, T. J., Maldonado, M. T. (2009): Plankton copper requirements and uptake in the subarctic Northeast Pacific Ocean. - Deep Sea Research Part I Oceanographic Research Papers 56: 1130-1142. 
[38] Semeniuk, D. M., Taylor, R. L., Bundy, R. M., Johnson, W. K., Cullen, J. T., Robert, M., Barbeau, K. A., Maldonado, M. T. (2016): Iron-copper interactions in iron-limited phytoplankton in the northeast subarctic Pacific Ocean. - Limnology \& Oceanography 61: 279-297.

[39] Shi, Y. Q., Sun, S., Zhang, G. T., Wang, S. W., Li, C. L. (2015): Distribution pattern of zooplankton functional groups in the Yellow Sea in June: a possible cause for geographical separation of giant jellyfish species. - Hydrobiologia 754: 43-58.

[40] Shumka, S., Špoljar, Tasevska, M. O. (2018): The Zooplankton of Lake Skadar/Shkodra: Species Diversity and Abundance. - Pešić, V., Kostianoy, A. G., Karaman, G. S. (eds.) The Skadar/Shkodra Lake Environment. Springer, Berlin.

[41] Sinistro, R. (2010): Top-down and bottom-up regulation of planktonic communities in a warm temperate wetland. - Journal of Plankton Research 32: 209-220.

[42] Špoljar, M., Habdija, I., Primc, H. B., Sipos, L. (2010): Impact of environmental variables and food availability on rotifera assemblage in the karstic barrage lake Visovac (Krka River, Croatia). - International Review of Hydrobiology 90: 555-579.

[43] Srifa, A. (2010): Factors Controlling Zooplankton Dynamics in a Subtropical Lake During Cyanobacterial Bloom Events. - University of Florida, Gainesville, FL.

[44] Steinberg, D. K., Condon, R. H. (2009): Zooplankton of the York River. - Journal of Coastal Research 10057: 66-79.

[45] Stephen, D. (2010): The relative importance of top-down and bottom-up control of phytoplankton in a shallow macrophyte-dominated lake. - Freshwater Biology 39: 699713.

[46] Sun, J., Feng, Y., Wang, D., Song, S., Jiang, Y., Ding, C., Wu, Y. (2013): Bottom-up control of phytoplankton growth in spring blooms in Central Yellow Sea, China. - Deep Sea Research Part II Topical Studies in Oceanography 97: 61-71.

[47] Sun, S., Huo, Y., Yang, B. (2010): Zooplankton functional groups on the continental shelf of the yellow sea. - Deep-Sea Research Part II 57: 1006-1016.

[48] Thompson, G. A., Dinofrio, E. O., Alder, V. A. (2013): Structure, abundance and biomass size spectra of copepods and other zooplankton communities in upper waters of the Southwestern Atlantic Ocean during summer. - Journal of Plankton Research 35: 610-629.

[49] Trevisan, G. V., Forsberg, B. R. (2007): Relationships among nitrogen and total phosphorus, algal biomass and zooplankton density in the central Amazonia lakes. Hydrobiologia 586: 357-365.

[50] Wetzel, R. G. (2001): Limnology. - Academic Press, San Diego, CA.

[51] Yeatman, H. C. (1959): Cyclopoida. Freshwater Biology. 2nd Ed. - Wiley, New York.

[52] Zhou, J., Qin, B., Han, X. (2018): The synergetic effects of turbulence and turbidity on the zooplankton community structure in large, shallow Lake Taihu. - Environmental Science \& Pollution Research 25: 1168-1175.

[53] Zuo, T., Wang, K. (2003): Length-dry weight relationship of Calanus sinicus in the southern part of the Yellow Sea. - Journal of Fisheries of China 27(Suppl.): 103-107. 